\title{
Association of culture of mouse urogenital complexes in media containing rodent sera with the appearance of primordial germ cell-like cells
}

\author{
T. Mayanagi*, K. Ito and J. Takahashi \\ Laboratory of Animal Science and Reproduction, Faculty of Agriculture, Iwate University, \\ Ueda Morioka-shi Iwate 020-8550, Japan
}

Primordial germ cells differentiate into germ cells and have the ability to reacquire totipotency. Mouse primordial germ cells are identified by alkaline phosphatase staining of the extraembryonic mesoderm, and they proliferate and migrate to reach the genital ridges. Mouse primordial germ cells have never been maintained in culture exclusively for longer than a week without differentiation or dedifferentiation. Moreover, primordial germ cells have not been proliferated with urogenital complexes in vitro, because gonad culture has never been successful. It was thought that primordial germ cells could proliferate in a culture of urogenital complex under modified medium conditions resembling those in vivo; however, organ culture of mouse gonad has been performed with fetal calf serum or equine serum, and those sera produce conditions different from those in vivo. Therefore, mouse urogenital complexes were cultured in media containing rodent sera. As a result, it was possible to proliferate primordial germ celllike cells outside gonads, and these cells very closely resembled primordial germ cells. In addition, motile primordial germ cell-like cells could be obtained. The ability to maintain primordial germ cell-like cells in culture by this intra-species culture method is important in the study of gametogenesis. Furthermore, this method is useful as a source of stem cells such as embryonic germ cells.

\section{Introduction}

Primordial germ cells (PGCs) differentiate into germ cells and are able to reacquire totipotency in order to generate offspring. Mouse PGCs are first identified as the alkaline phosphatase-positive cells in an extraembryonic mesoderm. Subsequently, PGCs proliferate and migrate to reach the genital ridges at about day 13.5 after mating (Ginsberg et al., 1990). The differentiation of the gonad starts after PGCs have migrated into the genital ridges (Minz and Russell, 1957; Tam and Snow, 1981; Ginsberg et al., 1990). The developing mouse gonads first become distinguishable by sex at day 12.5 after mating (Byskov, 1986; Mackay and Smith, 1989). PGCs play an important role related to somatic cells in the organogenesis of the gonad. Therefore, the study of PGC proliferation and differentiation is important for understanding the mechanism of gonad formation.

Mouse PGCs have not been cultured exclusively and they have not been maintained in culture for a long period, because PGCs change their character very easily both in vivo and in vitro. PGCs are affected by some factors from somatic cells or the extracellular matrix.

*Address for correspondence: Kannondai Terrace House E-101, 1-9-9 Kannondai, Tsukuba-shi, Ibaraki 305-0856, Japan Email: ohnuma@affrc.go.jp
For example, Steel factor (SCF) (Godin et al., 1991) and transforming growth factor $\beta$ (TGF- $\beta$ ) (Godin and Wylie, 1991) are regulatory factors of proliferation and migration. In previous studies, embryonic germ (EG) cells were obtained when mouse PGCs were cultured with SCF, leukaemia inhibitory factor (LIF) (Matsui et al., 1991) and basic fibroblast growth factor (bFGF) (Resnick et al., 1992). EG cells are known as totipotent stem cells and are different from PGCs.

Gonad culture has been used for the study of proliferation and differentiation of PGCs. Tissue culture is a useful technique for understanding the mechanisms of gametogenesis, for example, meiosis, genomic imprinting and signal transduction in germ cell and neighbouring somatic cells. However, PGCs could not be proliferated in urogenital complexes in vitro, because gonad culture has been difficult to perform.

Some researchers have reported culture of urogenital complexes at each stage of development (Taketo and Koide, 1981; Mackay et al., 1986; Agelopoloul and Magre, 1987; Mackay and Smith, 1989; Tilmann and Capel, 1999). In a recent study, gametegenesis in vitro had limited success (Eppig and O'Brien, 1996) or required skilful manipulation techniques (Obata et al., 2002). Some reports show that the serum generally improved the development, growth and stimulation of mitosis in cultures of gonads. The culture of urogenital 
complexes before the migrating stage of PGCs was attempted using equine serum (Taketo and Koide, 1981 ) and the urogenital complexes were capable of differentiation in vitro. Recently, urogenital complexes just at the start of the differentiation stage were cultured in a medium containing $10 \%$ fetal calf serum (FCS) for 30-44 h (Tilmann and Capel, 1999). Furthermore, Obata et al. (2002) reported the successful in vitro maturation of mouse oocytes with the combination of organ culture of gonad and nuclear transplantation. These authors used Waymouth medium containing $10 \%$ fetal bovine serum. However, there are some reports that the serum has an inhibitory effect on organ culture (Agelopoloul and Magre, 1987; Mackay and Smith, 1989). A culture medium containing $15 \%$ FCS prevented the differentiation of testicular cords when the rat urogenital complexes were cultured for 4 days before sexual differentiation (Agelopoulou et al., 1984). It was suggested by Agelopoloul and Magre (1987) that Sertoli cells secrete Mullerian inhibitor despite the absence of testicular cord formation in a culture with serum. In almost all cases, FCS or equine serum have been used as a supplement in the medium of organ culture. Namely, the addition of serum has been reported to produce an inhibitory effect but also some advantages in the differentiation of mouse gonad in vitro.

In the organ culture of mouse gonad in vitro, the cells emerge outside the male gonad on day 13 after mating (Byskov, 1978). In addition, characteristic round granular cells (RGCs) appeared outside the gonad cultured with equine serum and these cells were stained by alkaline phosphatase (MacLaren, 1983). However, there was no detailed description concerning the emergence of the round granular cells outside the gonad, the relation to PGC-like cells, and serum.

The present study examined whether PGCs could proliferate using urogenital complexes cultured with modified conditions using more appropriate sera. Previously, tissue culture of mouse gonad was carried out with FCS or horse serum. These cross-species conditions were different from the environmental conditions in vivo. In fact, some cross-species reactivities between mouse and cattle or horse were reported (Levery and Wainer, 1982; Diamond et al., 1991), but these activities were low (Abreu et al., 1981). Therefore, mouse urogenital complexes were cultured with rodent sera in this study.

\section{Materials and Methods}

Mice and embryos

ICR/Jcl mice (Mus musculus) obtained from Clea, Japan, Inc. (Tokyo) were used in this study. The adult female mice (about 2-3 months of age) were placed with males overnight; vaginal plugs were examined on the next morning and the mice were kept in a closed colony with $12 \mathrm{~h}$ light: $12 \mathrm{~h}$ dark cycle at $23^{\circ} \mathrm{C}$. The day on which a vaginal plug was found was defined as day 1 after mating. Female mice at day 12.5 after mating were killed by dislocation of the cervical spine and embryos were collected in the tissue culture dish (Terumo Corporation, Tokyo) in PBS. Urogenital complexes (mesonephros and genital ridge) were obtained by microsurgery using the method of Cooke et al. (1993).

\section{Organ culture of urogenital complexes}

The organ culture was performed with the cell culture insert (Falcon, Becton Dickinson and Co., Franklin Lakes, $\mathrm{NJ})$ of $0.4 \mu \mathrm{m}$ pore size within a 24-well tissue culture plate (Falcon, Becton Dickinson and Co.). Dulbecco's modified eagle's medium (DMEM; Sigma, St Louis, MO)

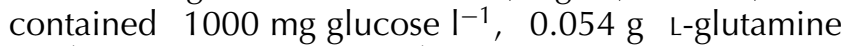
$\mathrm{ml}^{-1}, 3.7 \mathrm{~g} \mathrm{NaHCO}_{3} \mathrm{ml}^{-1}$ and $0.0004 \mathrm{~g}$ pyridoxine $\mathrm{HCl} \mathrm{ml}{ }^{-1}$, supplemented with $25 \mathrm{mmol}$ Hepes (Wako Pure Chemicals Industries, Osaka), 50 units penicillin $\mathrm{G}$ sodium $\mathrm{ml}^{-1}$ and $50 \mu \mathrm{g}$ streptomycin sulphate $\mathrm{ml}^{-1}$ (Gibco, Grand Island, NY) as the control medium. The various animal sera were added to the control medium as $10 \%$ of the total volume of the experiment medium. Fetal calf serum (FCS; Gibco), horse, rat and mouse sera were used in this experiment. Sera of mice and rats were obtained from males, non-pregnant females, and pregnant females (day 12.5 after mating), respectively. The blood was obtained from horses, rats and mice, and the sera were separated. A set of urogenital complexes of 12.5 days after mating was placed on a cell culture insert membrane per well. These complexes were cultured at $37^{\circ} \mathrm{C}$ in air, $5 \% \mathrm{CO}_{2}$ and the medium was changed on alternate days during the culture period. These organs were cultured for 7 days.

\section{Identification of PGC-like cells and observation of tissue structure}

The identification of PGC-like cells was accomplished by alkaline phosphatase (ALP) staining, carried out by the azo dye method of Brinster and Harstad (1977) that used naphthol AS-MX phosphate (Sigma) as the substrate of Fast blue RR salt (Sigma) as the dye. The cultured complexes were fixed with $10 \%$ formalin, $0.013 \mathrm{~g} \mathrm{CaCl}_{2} \cdot \mathrm{H}_{2} \mathrm{O} \mathrm{ml}^{-1}$ solution $\left(4^{\circ} \mathrm{C}, 15-20 \mathrm{~min}\right)$. After treatment, each well was washed five times with distilled water, and the reactive solution was added. The reactive solution containing 0.05 mol Tris buffer $\mathrm{I}^{-1}$ solution was added with the substrate and azo dye. The cells outside the genital ridges were stained at days 3 and 7 of culture by ALP staining, and the number of ALP-positive cells was counted under a microscope. In the present study, the number of PGC-like cells was counted. Then, the tissue structure inside the organs was observed by paraffin wax section. The cultured organ was dehydrated in ethanol $\left(4^{\circ} \mathrm{C}\right)$ for $24 \mathrm{~h}$ and embedded in paraffin wax and sectioned at $8 \mu \mathrm{m}$ thickness. Each 

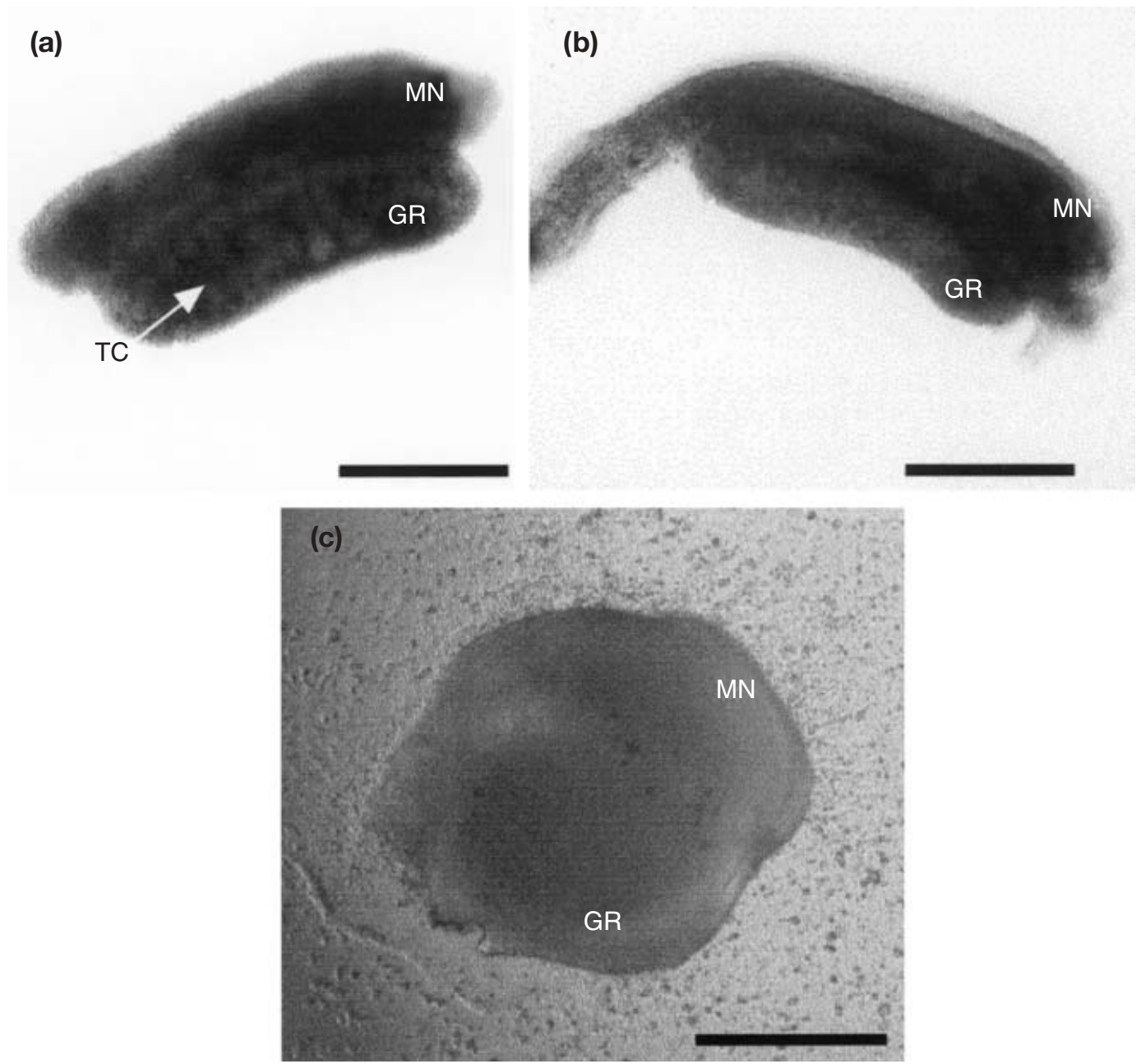

Fig. 1. Mouse urogenital complex before culture at day 12.5 after mating and gonad cultured for 7 days with serum-free medium. (a) Male and (b) female urogenital complexes could be distinguished by the presence of primitive testicular cords (TC) in the male. (c) Male urogenital complex cultured for 7 days with serum-free medium. MN: mesonephros; GR: genital ridge. Scale bars represent $500 \mu \mathrm{m}$.

section was stained by eosin and observed under a light microscope.

\section{Statistical analysis}

Data for numbers of PGC-like cells were expressed as means \pm SD. The statistical analysis was carried out using Student's $t$ test. Significance was considered as $P<$ 0.05. Experiments were examined at least in triplicate.

\section{Results}

Influence of various sera for structure of mouse urogenital complexes in vitro

The urogenital complexes of fetal mice on day 12.5 after mating began to show sexual differentiation. The sex of gonads could be determined before culture because primitive testis cords were observed (Fig. 1a,b). In the control medium (serum-free), the tubules of the primitive testis cords extended and formed the testicular structures in male genital ridges after day 7 of culture (Fig. 1c). The extension of primitive testis cords was observed in male gonads at day 3 of culture. However, the female genital ridges cultured with the serum-free medium, FCS or horse serum did not change into any characteristic structure during these periods. These cultured organs changed into round structures. However, in the culture of organs with media containing mouse or rat serum, many round granular cells were observed outside the urogenital complex (Fig. 2a). These round granular cells appeared on the monolayer of fibroblast-like cells around the gonad, and these round granular cells were stained by ALP (Fig. 2b). Only fibroblast-like cells were observed in the culture containing FCS or equine serum (data not shown). 

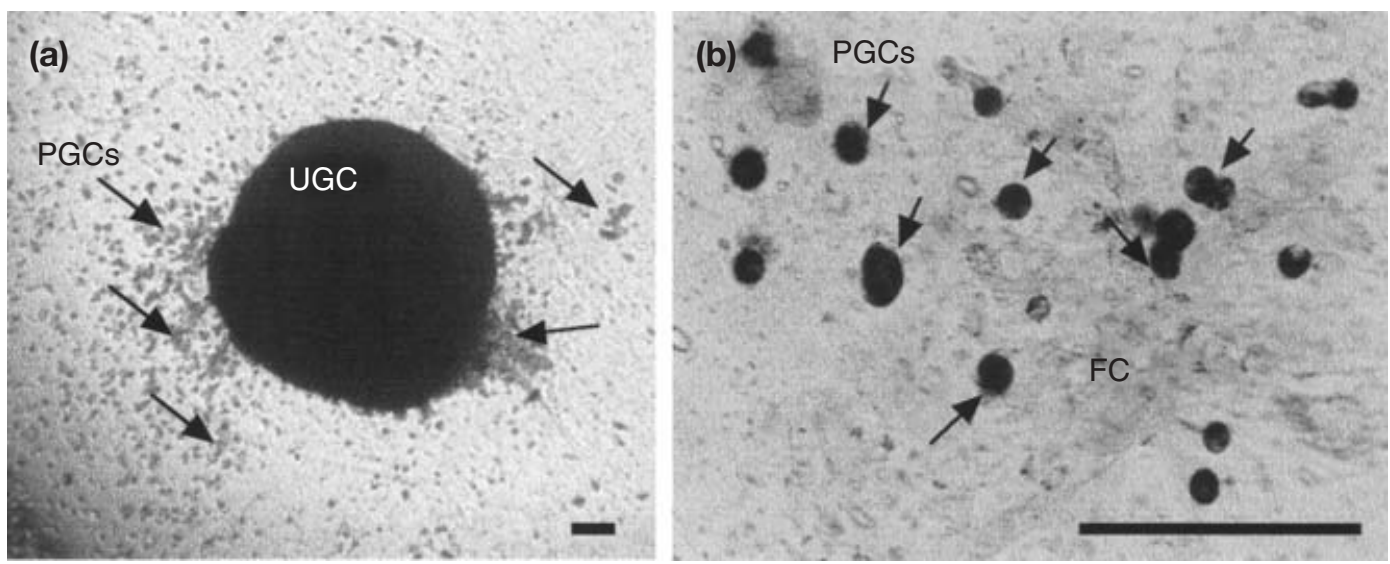

Fig. 2. Mouse primordial germ cell-like cells (PGCs) appeared around the urogenital complex. (a) Urogenital complex cultured for 7 days with male mouse serum was surrounded by PGCs (arrows). (b) High magnification of (a). UGC: urogenital complex, FC: fibroblast-like cells. PGCs were stained using alkaline phosphatase. Scale bars represent $100 \mu \mathrm{m}$.

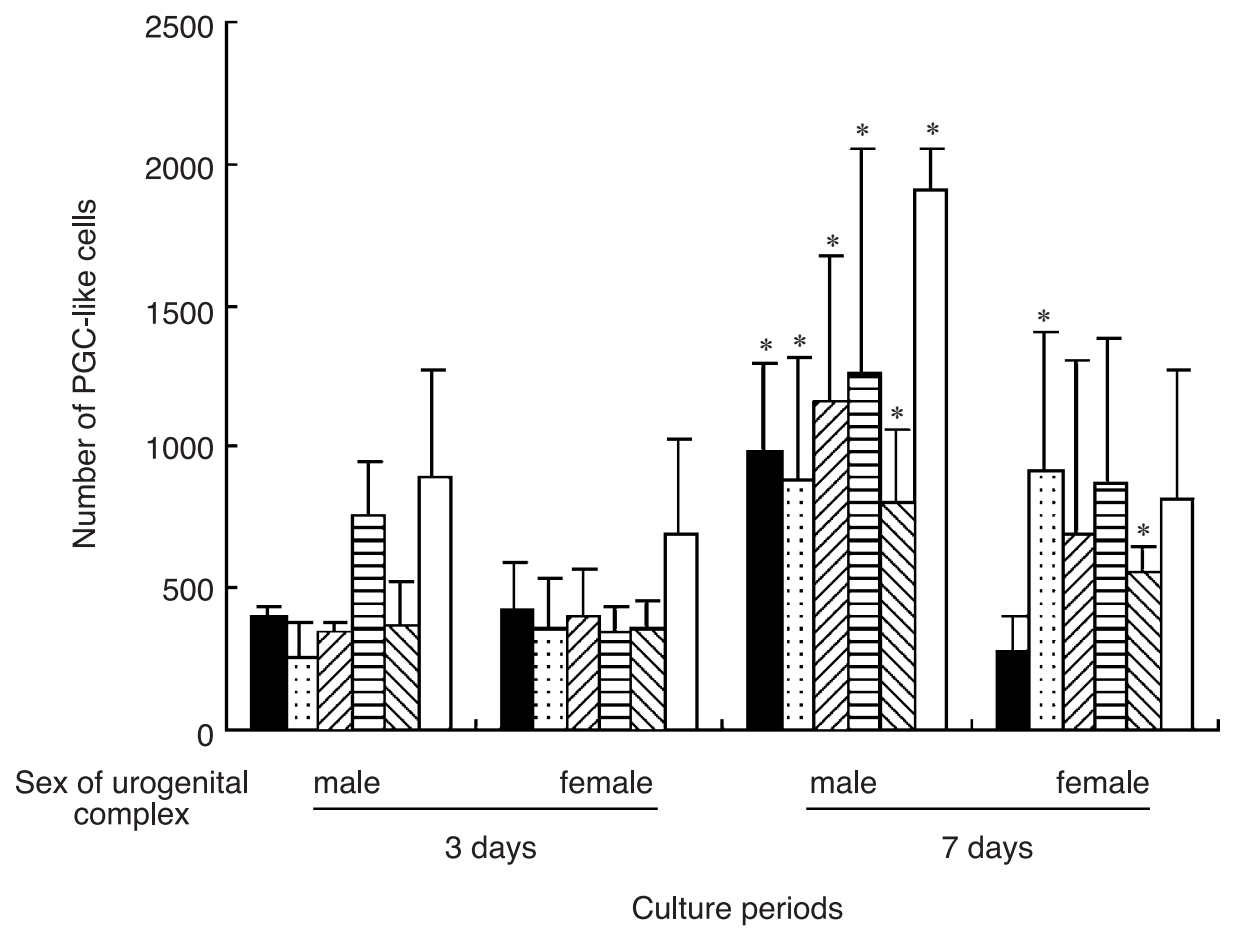

Fig. 3. Increase of primordial germ cell (PGC)-like cells outside urogenital complexes cultured with mouse and rat serum. $\mathbf{a}:$ Mouse male serum ${ }^{\dagger}$; 国: mouse female serum; $\mathbb{V}$ : mouse pregnant serum; 巨: rat male serum; 芯: rat female serum ${ }^{\dagger} ; \square$ : rat pregnant serum ${ }^{\dagger} .{ }^{*}$ Number of PGC-like cells at day 7 of culture are significantly increased compared with day 3 culture $(P<0.005)$. ${ }^{\dagger}$ Significantly increased urogenital complex in males compared with females $(P<0.005)$. Bars represent mean $\pm \mathrm{SD}$.

\section{Effects of rodent serum for PGC-like cells}

PGC-like cells emerged outside the medium when rat or mouse serum were used. When gonads were cultured with rodent sera for 2 days, PGC-like cells appeared around the urogenital complexes. The number of these cells increased with time of culture (Fig. 3).

In all culture media containing mouse sera, the number of PGC-like cells outside of the male gonads increased to about 1000 at day 7 of culture. In contrast, 

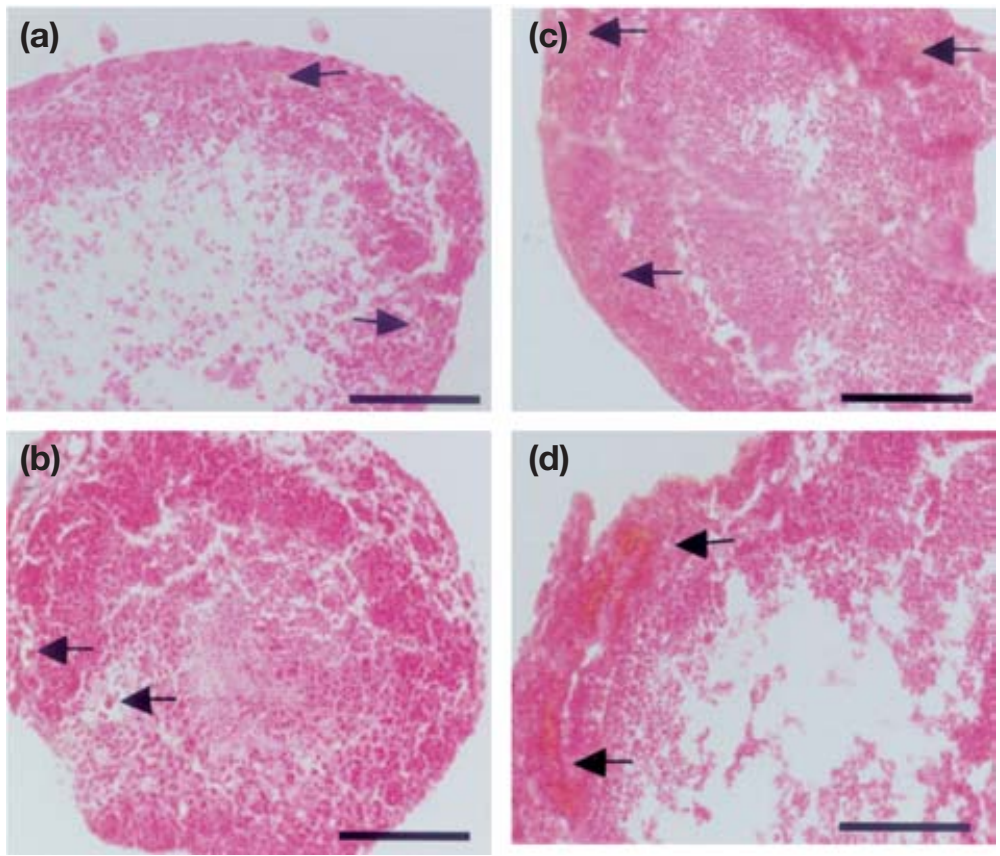

Fig. 4. Changes in $(a, c)$ male or $(b, d)$ female mouse urogenital complexes cultured for 7 days in medium supplemented with $(a, b)$ male mouse serum or $(c, d)$ male rat serum. These sections were stained by alkaline phosphatase and eosin. Arrows show primordial germ cell-like cells stained by alkaline phosphatase. Scale bars represent $200 \mu \mathrm{m}$.

the increase in the number of PGC-like cells outside of female gonads was only almost half that observed outside male gonads.

In the rat serum, PGC-like cells outside of the male gonad increased in number to approximately $1300 \mathrm{com}-$ pared with 800 for the female gonad at day 7 of culture. This effect also occurred with mouse serum (Fig. 3). Particularly, in the pregnant rat serum, the number of PGC-like cells outside of the male gonads increased to about $2000(1912 \pm 143)$ at day 7 of culture. There were some differences for each rat serum; serum from nonpregnant rats had little effect $(563 \pm 83$ from female gonad) and serum from pregnant rats had a large effect (1912 \pm 143 from male gonad) in increasing the number of PGC-like cells. However, only a few PGC-like cells and small spherical cells outside the gonads were observed during the culture periods in FCS $(<50)$, equine serum $(<20)$ and the serum-free medium (none or a few) (data not shown).

\section{Changes of the internal structure of genital} ridges in culture

Increased numbers of PGC-like cells appeared outside the urogenital complexes cultured in medium containing the rodent sera. It is possible that the number of PGC-like cells inside the gonad increased or decreased after the emergence of PGC-like cells outside the gonad during organ culture. Changes in the organ structures and the distribution of ALP-positive PGC-like cells were observed in tissue sections (Fig. 4).

Almost all organs cultured with media containing rodent sera had cleft spaces in the urogenital complex (Fig. 4). Before culture, many PGC-like cells were observed inside the genital ridges (Fig. 5a,b). However, few PGC-like cells were observed in the cultured urogenital complexes. These PGC-like cells were located near the surface of the tissue (Fig. 4). In the urogenital complexes cultured with FCS, the morphology of the gonads did not change, and few ALP-positive cells were found inside the organs (Fig. 5e,f). These results were similar to those in the serum-free medium: cells positive for ALP did not appear outside the tissues in the serum-free medium (Fig. 5c,d). Cells positive for ALP were observed in a primitive testicular cord-like structure (Fig. 5c). Urogenital complexes cultured with horse serum were similar to those cultured with FCS (data not shown).

\section{Discussion}

The objective of this study was to achieve the proliferation of PGCs in culture. In this study, PGC-like cells emerged outside gonads cultured with rodent sera and proliferated in this culture medium.

The successful maturation of mouse germ cells in vitro was reported using serum (Eppig and O'Brien 1996; 

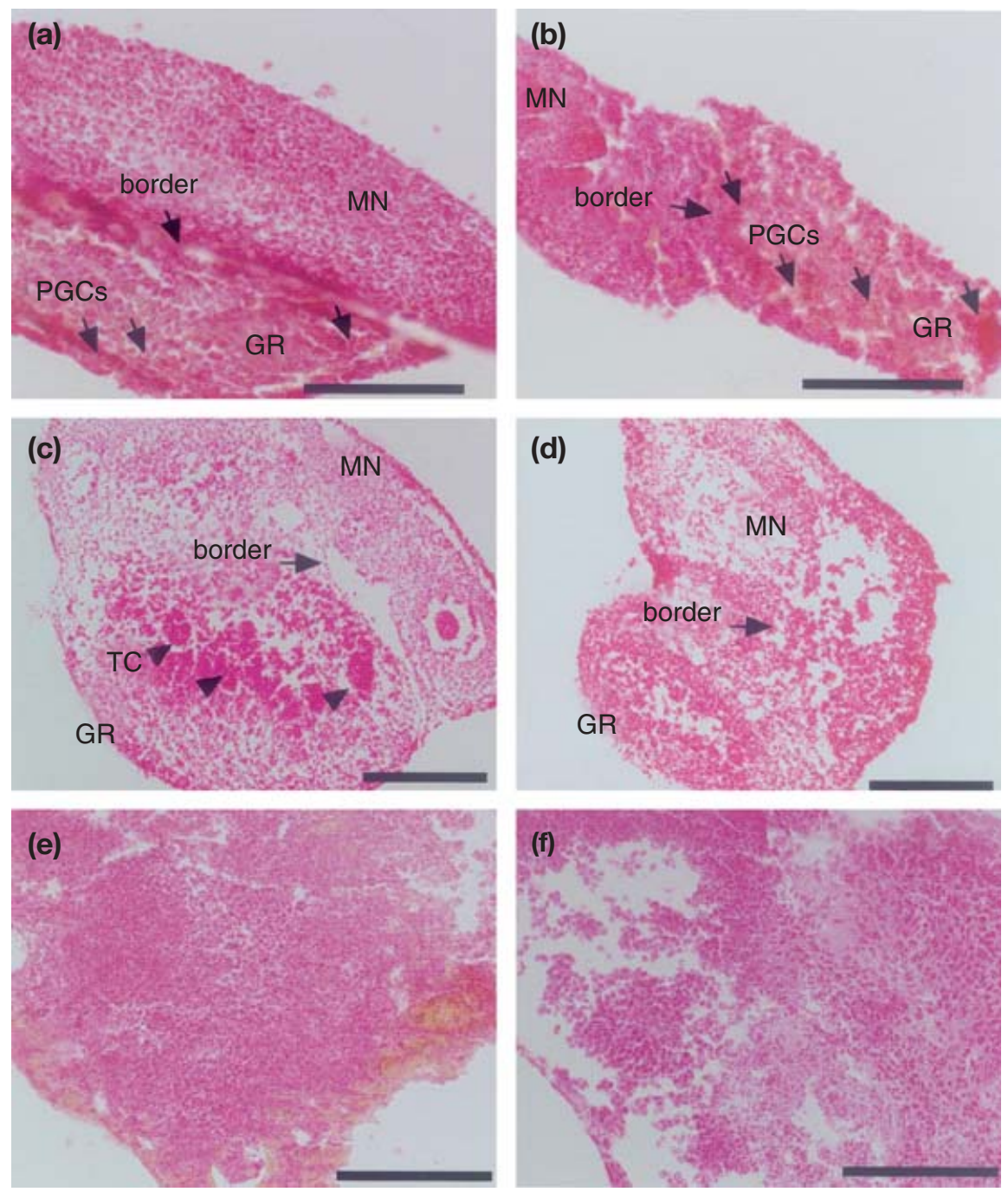

Fig. 5. Mouse urogenital complexes at day 12.5 after mating $(a, b)$ before culture and changes in urogenital complexes with $(c, d)$ serum-free medium or $(e, f)$ fetal calf serum. $(\mathrm{a}, \mathrm{c}, \mathrm{e})$ Male gonad; $(\mathrm{b}, \mathrm{d}, \mathrm{f})$ female gonad. Sections were stained by alkaline phosphatase and eosin. MN: mesonephros, GR: genital ridge, TC: primitive testicular cord-like structure, PGCs: primordial germ cell-like cells stained by alkaline phosphatase. Scale bars represent $200 \mu \mathrm{m}$.

Obata et al., 2002). It required changes in the medium conditions during culture periods and skilful techniques (Obata et al., 2002). In a previous study, germ cells have been able to progress up to the diplotene stage of the first meiosis without nuclear transplantation. Therefore, it was thought that serum in the medium has an important role in the initial condition of gonad culture in vitro. However, there have been no reports using sera other than FCS or horse serum for the culture of the urogenital complex. These conditions are different from the in vivo environment of mice. Cross-species reactivity was reported but rat fibroblast-derived interferon had low reactivity in cattle and high reactivity in mice (Aberu et al., 1981). Therefore, unidentified factors in sera were thought to act effectively in the intra-species culture. In the present study, we examined the culture of urogenital complexes containing rodent sera in order to approximate the conditions in vivo; as a result, round granular cells appeared outside the gonads. These round granular cells resembled PGCs, being stained by ALP and being morphologically similar (Chiquoine, 1954). In previous reports, the fibroblast-like cells and round cells were described outside the gonads in serum-free medium or horse serum (Byskov, 1978; McLaren, 1983). In the present study, the fibroblast-like cells observed were similar to those in previous reports, but the round cells emerged from the urogenital complexes cultured with rodent serum and did not emerge in the serumfree medium. It is thought that the appearance of PGCs reported by Byskov (1978) and McLaren (1983) was via 
the use of the genital ridges without mesonephros, and it was thought that the genital ridges had been damaged by microsurgery. The c-kit and SCF were reported as being the factors related to migration of PGCs (Matsui et al., 1991, 1992; Pesce et al., 1997). SCF is expressed on the path toward the genital ridges and fibroblast cells, and C-kit is expressed on PGCs. It was also reported that PGCs emerged from epiblasts at day 6.0-6.5 after mating on STO feeder cells or on fibronectin (Yoshimizu et al., 2001). Fibronectin is an extracellular matrix that is related to adhesion and migration of cells (Berrios et al., 2001; Park et al., 2001). Some motile PGC-like cells were observed in the present study. It was suggested that PGC-like cells appearing outside the gonads might involve these factors, because PGC-like cells adhered to fibroblast-like cells, and many migrating PGC-like cells were observed in this study.

In addition, PGC-like cells increased in numbers, maintaining ALP activity in cultures with rodent sera in vitro. This result showed that the increase in number of PGC-like cells was greater than that of PGCs derived from embryos at day 11.5 after mating (Koshimizu et al., 1996). Three reasons are proposed to account for the appearance and proliferation of PGC-like cells outside the gonads: (1) The medium supplemented with rodent serum was similar to that inside the gonads, (2) PGCs emerged outside the gonads because of the increase in number of PGCs, which filled the gonads, and (3) PGCs moved to the outside of the gonads, because the internal structures of the cultured organ were disorganized and changed the internal environment. Generally, the number of germ cells decreases sharply when meiosis is initiated; Allan et al. (1987) reported that this decrease occurs by apoptosis. Apoptosis factors are expressed in gonads (De Felici et al., 1999; Reynaud and Driancourt, 2000; Riccioli et al., 2000; Xu et al., 2000). Fas, Fasligand, and Bax are expressed in adult and fetal testis (Francavilla et al., 2000; Rucker et al., 2000). The ovary expresses Fas-ligand (Guo et al., 1997), Bax (De Felici et al., 1999) and TGF- $\beta$ (Kolaja and Klaassen, 1998). In addition, Fas and Fas-ligand are present in the serum (Iwama et al., 2000). Saito et al. (1999) suggested that the Fas-ligand in the serum is able to cause damage to the tissues. If cells inside of the gonads expressed apoptosisinducing factors, it was thought that the supplemented sera disorganized the structures of fetal gonads, and PGCs lost the locations where they normally differentiate and they emerged outside the gonads via the SCF and c-kit system, or the motility affected the extracellular matrix between fibroblast cells. The marked increase in PGC-like cells and the disorganization might therefore be caused by factors derived from rodent sera in the intra-species culture compared with the other sera. More studies on the emergence of PGC-like cells may elucidate the mechanism of migration of PGCs.

PGCs at day 12.5 after mating have the capability to differentiate gametes and dedifferentiate stem cells. The disappearance of totipotency and differentiation of PGCs might be related to the fact that the majority of genomic imprinting is erased during 11-12 days after mating (Tada et al., 1998; Durcova-Hills et al.,, 2001; Obata et al., 2002). However, the entire process of genomic imprinting and maturation factors has never been clarified. PGCs are an interesting source for the study of meiosis, genomic imprinting, mobility and totipotency. Therefore, this method of culturing PGC-like cells is important in the study of gametogenesis, because this method is useful in maintaining PGCs in vitro. Furthermore, by using this method, it is thought that EG cells may be easily obtained, and thus this method may be useful in studying stem cells and germ cells.

The authors thank P. Langman for his kind assistance with the preparation of the paper.

\section{References}

Abreu SL, Cannella MS and Hanke J (1981) Induction and cross-species activity of rat fibroblast-derived interferon Microbios 30 181-190

Agelopoloul RS and Magre EP (1987) Expression of fibronectin and laminin in female male gonads in vivo and in vitro and without testicular morphogenesis Cell Differentiation 21 31-36

Agelopoloul RS, Magre EP and Jost A (1984) Initial phase of the rat testis differentiation in vitro. Journal of Embryonal Experimental Morphology 83 15-31

Allan DJ, Harmon BV and Kerr JFR (1987) Cell death in spermatogenesis. In Perspectives on Mammalian Cell Death pp 229-258 Ed. CS Potten. Oxford University Press, Oxford

Berrios VM, Dooner GJ, Nowakowski G, Frimberger A, Valinski H, Quesenberry PJ and Becker PS (2001) The molecular basis for the cytokine-induced defect in horming and engraftment of haematopoietic stem cells Experimetal Hematology 29 1326-1335

Brinster RL and Harstad H (1977) Energy metabolism in primordial germ cells of the mouse Experimental Cell Research 109 111-117

Byskov AG (1978) Regulation of initiation of meiosis in fetal gonads International Journal of Andrology 2 Supplement 29-38

Byskov AG (1986) Differentiation of mammalian embryonic gonad Physiological reviews 66 71-117

Chiquoine AD (1954) The identification, origin, and migration of the primordial germ cells in the mouse embryo Anatomical Record 118 135-145

Cooke JE, Godin I, Constant CF, Heasman J and Whlie CC (1993) Culture and manipulation of primordial germ cells In Guide to Techniques in Mouse Development. Methods in Enzymology Vol. 225 pp 37-77 Eds PM Wassarman and ML DePamphilis. Academic Press, Burlington, MA

De Felici M, Carlo AD, Pesce $M$, Iona S, Farrace MG and Piacentini M (1999) Bcl-2 and Bax regulation of apoptosis in germ cells during prenatal oogenesis in the mouse embryo Cell Death and Differentiation 6 908-915

Diamond G, Scanlin TF, Zasloff MA and Bevins CL (1991) A cross-species analysis of the cystic fibrosis transmembrane conductance regulator. Potential functional domains and regulatory sites Journal of Biological Chemistry 30 181-190

Durcova-Hills G, Ainscough JFX and McLaren A (2001) Pluripotential stem cells derived from migrating primordial germ cells Differentiation 68 220-226

Eppig JJ and O'Brien MJ (1996) Development in vitro of mouse oocytes from primordial follicles. Biology of Reproduction 54 197-207

Francavilla S, D'Abrizio P, Rucci N, Silvano G, Properzi G, Straface E, Cordeschi G, Necozione S, Gnessi L, Arizzi M and Ulisse S (2000) Fas and Fas ligand expression in fetal and adult human testis with 
normal or deranged spermatogenesis Journal of Clinical Endocrinology and Metabolism 85 2692-2700

Ginsberg M, Snow MHL and McLaren A (1990) Primordial germ cells in the mouse embryo during castration Development 110 521-528

Godin I and Wylie CC (1991) TGF $\beta 1$ inhibits proliferation and has a chemotropic effect on mouse primordial germ cells in culture Development 113 1451-1457

Godin I, Deed R, Cooke J, Zsebo K, Dexter M and Wylie CC (1991) Effect of the steel gene product on mouse primordial germ cells in culture Nature 352 807-809

Guo MW, Xu JP, Mori E, Sato E, Saito S and Mori Tsuneatsu (1997) Expression of Fas ligand in murine ovary American Journal of Reproductive Immunology 37 391-398

Iwama H, Akutsu H, Kuretake S, Tohma J and Nakamura N (2000) Serum concentrations of soluble Fas antigen and soluble Fas ligand in mother and newborn Archives of Gynecology and Obstetrics 263 108-110

Kolaja KL and Klaassen CD (1998) Dose-response examination of UDPglucuronosyltransferase inducers and their ability to increase both TGF-beta expression and thyrod follicular cell apoptosis Toxicological Science 46 31-37

Koshimizu U, Taga T, Watanabe M, Saito M, Shirayoshi Y, Kishimoto T and Nakatsuji N (1996) Functional requirement of gp130-mediated signaling for growth and survival of mouse primordial germ cells in vitro and derivation of embryonic germ (EG) cells Development 122 1235-1242

Levery Al and Wainer BH (1982) Cross-species and intraspecies reactivity of monoclonal antibodies against choline acetyltransferase Brain Research 234 469-473

McLaren A (1983) Studies on mouse germ cells inside and outside the gonad Journal of Experimental Zoology 228 167-171

Mackay S and Smith RA (1989) Mouse gonadal differentiation in vitro in the presence of fetal calf serum Cell Differentiation and Development 27 19-28

Mackay S, Smith RA and Mackenzie C (1986) Effect of serum on differentiation of mouse gonads in vitro. Journal of Anatomy 149 Supplement 241

Matsui Y, Toksov D, Nishikawa S, Nishikawa S, whilliams D, Zsebo K and Hogan BLM (1991) Effect of steel factor and leukaemia inhibitory factor on murine primordial germ cells in culture Nature 353 750-752

Matsui Y, Zsebo K and Hogan BLM (1992) Derivation of pluripotent embryonic stem cells from murine primordial germ cells in culture Cell 70 841-847

Minz B and Russell ES (1957) Gene-induced embryological modifications of primordial germ cells in the mouse Journal of Experimental Zoology 134 207-237

Obata Y, Kono T and Hatada I (2002) Gene silencing: maturation of mouse fetal germ cells in vitro. Nature 418 497-498
Park JC, Park BJ, Suh H, Park BY and Rah DK (2001) Comparative study on motility of the cultured fetal and neonatal fibroblasts in extracellular matrix Yonsei Medical Journal 42 587-594

Pesce M, Carlo AD and Felici MD (1997) The c-kit receptor is involved in the adhesion of mouse primordial germ cells to somatic cells in culture Mechanisms and Development 68 37-44

Resnick JL, Bixler LS, Cheng L and Donovan PJ (1992) Long-term proliferation of primordial germ cells in culture Nature 359 550-551

Reynaud K and Driancourt MA (2000) Oocyte attrition Molecular and Cellar Endocrinology 163 101-108

Riccioli A, Starace D, D'Alessio A, Starace GM, Padula F, De-Cesaris P, Filippini A and Ziparo E (2000) TNF-alpha and INF-gamma regulate expression and function of the Fas system in the seminiferous epithelium Journal of Immunology 165 743-749

Rucker EB, Dierisseau P, Wagner K, Garrett L, Wynshaw-Boris A, Flaws JA and Henninghausen $\mathbf{L}$ (2000) $\mathrm{BCl}-\mathrm{x}$ and Bax regulate mouse primordial germ cell survival and apoptosis during embryogenesis Molecular Endocrinology 14 1038-1052

Saito M, Nakamura N, Nagai M, Shirakawa K, Sato H, Kawahigashi N, Furukawa Y, Usuku K, Nakagawa M, Izumo S and Osame M (1999) Increased levels of soluble Fas ligand in CSF of rapidly progressive HTLV1 associated myelopathy/tropical spastic paraparesis patients Journal of Neuroimmunology 98 221-226

Tada T, Tada M, Hilton K, Barton SC, Sado T, Takagi N and Surani MA (1998) Epigenotype switching of imprintable loci in embryonic germ cells Development, Genes and Evolution 207 551-561

Taketo T and Koide SS (1981) In vitro development of testis and ovary from indifferent fetal mouse gonads Developmental Biology 84 61-66

Tam PPL and Snow MHL (1981) Proliferation and migration of primordial germ cells during compensatory growth in mouse embryos Journal of Embryology and Experimental Morphology 64 133-147

Tilmann C and Capel B (1999) Mesoneprotic cell migration induces testis cord formation and sertoli cell differentiation in mammalian gonad Development 126 2883-2890

Xu J, Xu Z, Jiang Y, Qjan X and Huang Y (2000) Cryptorchidism induces mouse testicular germ cell apoptosis and changes in bcl-2 and bax protein expression Journal of Environmental Pathology, Toxicology and Oncology 19 25-33

Yoshimizu T, Obinata M and Matsui Y (2001) Stage-specific tissue and cell interactions play key roles in mouse germ cell specification Development 128 481-490

Received 15 July 2002.

First decision 21 November 2002.

Revised manuscript received 9 December 2002.

Accepted 13 January 2003. 